\title{
Political Reconstruction of Law towards the Rights of Non-Marital Child through the State Recognition of Unregistered Marriage in Indonesia
}

\author{
Herni Widanarti ${ }^{1}$, Benny Riyanto ${ }^{2}$, Yunanto Yunanto ${ }^{3}$ \\ \{herniwidanarti13@gmail.com¹,dr.bennyriyanto@yahoo.com²,,yun_yunanto@yahoo.com ${ }^{3}$ \} \\ Diponegoro University, J1.Prof. H. Soedarto, S.H. Tembalang, Tembalang, Kota Semarang, Jawa \\ Tengah, 50275, Indonesia
}

\begin{abstract}
It should be noted in Indonesia that daily practice of law shows there has been a legal pluralism caused by civil relations among its people who daily hold on to religious law, customs law, or entirely subjected to the national law. As an implication of legal pluralism, there is a collision amongst them. The pluralistic people also affect the implementation of marriage, which only relies on religious law or their beliefs, without registering their marriage as an act of law based on Law no. 1 of 1974 on Marriage. As a result, there would be no authentic proof of marriage as a legal act that causes the children born out of the legal wedlock, hence illegitimate children have less legal protection and guardianship to their biological parents. This provision was soon to be discontinued as The Constitutional Court ruled that the child born out of unregistered marriage can validate his/her legal relationship with biological parents based on scientific tests or other legitimate means of validation. The conclusion of this paper is first, judges deciding the case with the positivistic way of thinking must be abandoned. This way of thinking positivistic is a way of thinking that bases itself on the rule, so judges must think progressively. Second, there is a need for reconstruction of the law, since the establishment of the law and its implementation are based on the values that are agreed upon the nation.

Keywords: Non-Marital Child, Unregistered Marriage, Reconstruction of Law,
\end{abstract} Constitutional Court Decision

\section{Introduction}

Marriage is human nature for fulfilling their livelihood and doing intimate biological action within their family. Regarding the relation of not more than two people (legal relationship), each of them has rights and responsibilities. It initiates the existence of objective law regulating this relation in the form of Marriage Law. This relation is stated in Law Number 1 the year 1974, Article 1 that "Marriage is an inner bond between man and woman as a couple of legal partner aiming to build a happy and everlasting family-based under God the Almighty." Then, in Article 2 section (1), marriage is legal if it is under the law of the couple's religion and beliefs. Furthermore, it states that "every marriage is listed under the applied law and regulation."

Indonesia is a diverse nation in which the citizens are of different ethnic, racial, and religious backgrounds which affects the waythe law is understood and implemented. The practice of law in Indonesia is multi-faceted as there are plural forms of legal systems other than the formal state law[1]. In terms of marriage, such legal pluralism shows that the marriage practices in Indonesia are regulated by not only one marriage law that is the state, but also that of religion and customary[2]. As its implication, Indonesian couples often find 
themselves obliged to perform three marriages; the formal, the religious, and the customary, albeit that the former is the only legally legitimate practice[3]. Plural society will impact the existence of the marriage, which is only based on religious law without listing as in Law Number 1 the Year 1974. Such complication is even exacerbated by the dualism of Islamic marriage law in Indonesia in which the religiously initiated marriage under Islamic tradition could still be left unregistered if it has not been registered, such marriage is called as nikahsirri[4]. Due to such diversity of legal order and systems in Indonesia society, marriages which are only initiated under non-formal laws (i.e., religion and custom) will not have legal evidence to verify their vow;so, making its offspring to be legally illegitimate or unrecognized by the state [5]. The negative impact of which could be severe to the offspring does not have complete legal protection which derived from both parents as the law only rules the biological mother as the first sole 'parent' of the illegitimate child[6].

The example of marriage under religious law with no listing (nikah Siri or nikah 'urfi) can be seen in Singarancang village and Setu Patok village in Mundu district, Cirebon regency, West Java. In Singarancang village, there are 375 householders (60\% from overall 755 householders) exercised such marriage, while in Setu Patok village, there are 675 householders which got married only under religious ceremony without pursuing a legal registration. They did it based on the reason of simple process and economic efficiency. Besides, those householders have shallow educational background making them unaware of the importance of marriage registration to be acknowledged by the state. Therefore, such traditional marriage norms, added with everyday practical difficulties, in Indonesia can persist even when a nation is undergoing a rapid transition of marriage law to a unified registration. [7] This shows that the marriage law in Indonesia lacks public compliance by which the more efficient and widely practiced traditional marriage practices have generated more problems on unregistered marriages[8].

Another model of the outside marriage relationship is based on tribal beliefs of Sedulur Sike custom (Samin), Baduy, etc. Practically, children born from that unregistered marriage (according to Kesatuan Masyarakat Hukum Adat/KMHA or the Association of Local Wisdom Community or religious law) will be considered as children outside of marriage which will not get the civil rights.

The Constitutional Court of Indonesia (CCI) created a breakthrough with the resolution Number 46/PUU-VIII/2010 on 17th February 2012, examining the provision of Law Number 1 the Year 1974 regarding Marriage, specifically Article 43 section (1) regarding Children Outside of Marriage. It is because the previous provider did not guarantee the justice of legal protection to the children.

The CCI Verdict Number No. 46/PUU/-VIII/2010 was changed to "children who were born outside of marriage has civil relation to their mother and maternal family while men who were proven as their father can be evidenced with scientific and technological basis and/or other evidence with legal basis to prove the blood connection, including the civil relation to their father". This Resolution raises reactions from the society and the ulama despite this status as the final appeal which should be implemented. As for the writer's opinion, this is the resolution of a judge with a progressive mindset to which substantive justice could be achieved; $\mathrm{CCI}$ is brave to enter the way which is not regulated under the law after they can emphasize the assurance to the judge and society in fulfilling the justice[9].

The implication of CCI Resolution regarding children outside of marriage can work in practical and academic fields (legal study). The Resolution of CCI No. 46/PUU-VIII/2010 regarding children outside of marriage was initiated as the harmonization of national law to 
global law (international law); since, the resolution provides the substantive justice which is impossibly reached only from Law of Marriage, especially in Article 43 section (1). It is because the law contradicts Pancasila and 1945 Constitution of Indonesia Article 28B section (2) and Article 28D section (2), which are related to the formulation of Human Rights (the rights of the child) and Global law in international law of Convention of the Rights of Child (CRC).

The 1945 Constitution of Indonesia is the necessary foundation of law. It is placed on the highest position of law which contains the norms which should be followed, upheld, and executed in every decision making and policymaking, whether by the government, legislatives and judicial entities as well as the society. Thus, in the developing national law system and politics of law, it should be maintained and protected as the fundamental value of the nation following the main principles of the nation, Pancasila in the Preamble of 1945 Constitution of Indonesia, and all articles as the underlying philosophy and constitution of the country.

\section{Methodology}

The research of this article is based on the doctrinal legal research by which research is construed upon a statute analysis and related phenomenon unto it [10]. The analysis is built on a normative analysis of secondary legal data that are the statute, other related legal texts, and literature. Nonetheless, the analysis will be based on court reasoning, which underlies the Constitutional Court Verdict No. 46/PUU-VIII/2010 is analyzed in the political context of legal pluralism and Pancasila. To do such, the analysis will be guided by these questions:

- What are the bases of CCI Judges to resolve unregistered marriage cases extraordinarily (out of Normative way)?

- As for maintaining the integrity of the specifications. Why does the acknowledgment of the state to unregistered marriage neglect the provision of justice and humanity to children's rights?

- How is the political construction of law to the acknowledgment of marriage based on Pancasila as the means to protect the children?

\section{Findings}

\subsection{First Question}

To answer the question of "What are the bases of CCI Judges to resolve marriage cases in Extra-Ordinary way (out of Normative way)?", these following two sub-sections are going to explain the cases.

\subsubsection{Judges' Freedom.}

The authority of judges is less authoritativeness or more authoritativeness. Less authoritativeness is when other actors involved in the judicial process have a stronger social position. Meanwhile, more authoritativeness means the verdicts of the judges are strongly influenced by social relation. Nonetheless, the Constitutional Court of Indonesia is proven to be essential as the ultimate pathway of resolving constitutional conflict and bring the democratic consolidation in which the constitutional recognition and protection upon 
human rights are the ultimate end[11]. Besides, people who become judges are educated differently in a different period. It shows that in the same or similar cases, the judge can take a verdict which is based on the factors. In the justice system of Indonesia, it can happen due to the principle of stare decisis (a principle which obliges judges to adjust the settlement of a case based on the verdicts made by previous judges in the same cases).

Nowadays, the chairman of the judge who decides the case with positivistic mindset has to be left out, since it does not provide substantive justice. Positivistic mindset is a mindset which is based on law, principle, or objective norms which should be upheld in all condition. Following the rule means right; while breaking, it means wrong. There is no compromise to the violation of the law. It is positivistic since it talks about the precise value of black and white. It becomes complicated because human is complex and dynamic that it is almost impossible to have precise regulation on everything that happens. The role of judges is vital because in deciding the settlement of the case, they should not only consider the positive law; but they should also find the appropriate law to be applied as their basis.

\subsubsection{Progressive Law Theory.}

The theory of progressive law from Satjipto Rahardjo was used as the analysis technique to answer the first problem. In the writers' opinion, the Resolution of CCI is based on the Progressive Law theory. The breakthrough done by CCI aimed to achieve substantive justice; that is to say, what is built by CCI is not merely written law. Instead, it is justice. In a specific limit, law and justice are different. Law is the tool to uphold justice, while justice is not merely the same to law. Philosophically, CCI wants to uphold justice as the soul of the law so that the law does not only become the tool to uphold justice.

The theory of progressive law is part of the unfinished process of searching for the truth. Satjipto Rahardjo initiated the spreading of progressive law idea, a Professor Emeritus from Faculty of Law in Universitas Diponegoro, Semarang, which contradicts to empirical facts about how the law works in the society as the disappointment and concern to the performance and quality of law enforcement in Indonesia at the end of 20th century. Progressive law departs from two primary components of law; they are rules and behavior.[12]

Progressive law is based on two main assumptions. First, the law is for human, and it is not conversable. Thus, the law is not for itself; instead, it is for something broader and more significant. Therefore, if there is a legal problem; the law should be reviewed and repaired, instead of the human, which is enforced to be inserted in the scheme of law [13]. The second central assumption is that law is not an absolute and final institution since law always exists. Law is an institution which is continuously built and changes itself to the better forms of perfection. Perfection can be verified on several factors, including justice, welfare, social awareness, etc. This is what is called as law as a process, in the law-making by Satjipto Rahardjo.

\subsection{Second Question}

To answer the question "Why does the acknowledgment of the nation to unregistered marriage neglect the provision of justice and humanity to children's rights?", these following two sub-sections are going to explain the cases.

3.2.1. Social Reality. There are two levels on how to define reality. In Muhadjirin Thohir, reality can be defined genuinely as a natural object or the being which has not been touched 
by people. The second definition is reality is people's construction result (written or oral) to certain things, event, or condition as stated in conceptual form.[14] The news from Kompas about the existence of mass marriage to 5115 couples in Istora Senayan on 28th January 2015 is a reality found in the society. That is to say; this news proves the existence of thousands or millions of couple whose marriages were not registered as what has been stated in the background. It reminds people that the marriage will not be done due to religious proximity from KMHA and religious institution. According to Ervin Goffman, there are 3 (three) components of self-reflection:[15]

1. We can reflect our appearance on others' opinion;

2. We can reflect what people supposed to value on our appearance, and

3. We can reflect a certain feeling of dignity or shame due to others' opinion upon us.

People can reflect these components if they become children outside of marriage. The wrong action directly or indirectly from the country indicates that the country has harmed the justice and humanity of the KMHA community, poor people, and children outside of marriage. The leading theory for the reconstruction of the country to marriage based on Pancasila as the protection tool for children is based on Triangular Concept of Legal Pluralism from Werner Menski. Menski states that various legal systems are obtained from 1) law of the nation (tradition/positivism), 2) religion/ethics/morality, and 3) habit where every legal system (and the following system) will interact to each other.

Those types of law create a convergent legal pluralism which can be pictured as follows.

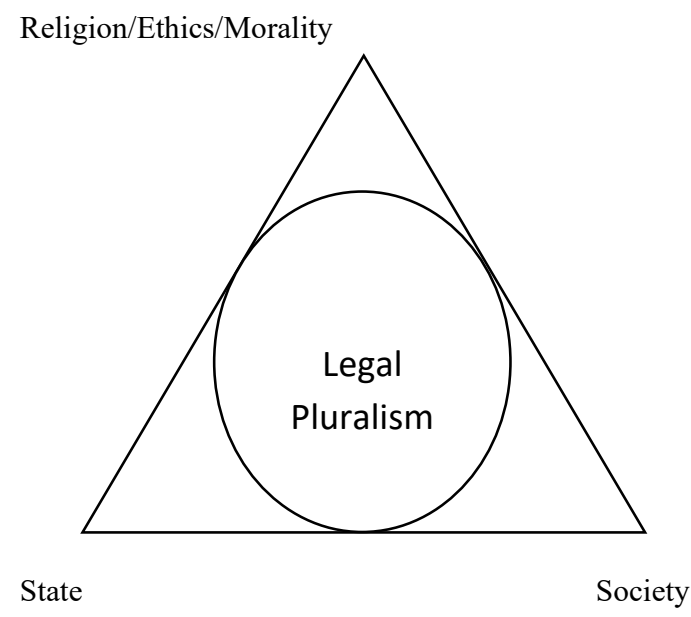

Stepping into the legal pluralism, Menski creates the triangle of law pluralism theory to analyze the legal system in Asia and Africa. All laws are plural. Like a tree, the law has three main elements to form a wood from the root which flow the blood for the life of the tree. It symbolizes the relationship between the society and the rooted norms which form the wood uniting all stakeholders (state's positivism) and branch which is directed to the sky to breathe and absorb lights (natural law). As there is not any tree which is the same; the law also works like that. 
3.2.2. Human Basic Rights. This second principle of Pancasila also becomes the foundation of law which appreciates and protects the non-discriminative fundamental rights of human[16].

Human rights or fundamental rights of human is initiated from the idea that humanity cannot be treated arbitrarily by power since a human has natural rights attached to them due to their humanity. Even if the basic principle of Human Rights' protection is based on individual freedom, the priority of individual here is not egoistic. It is because Human Rights are managed in social prerequisites that individual freedom is usually understood in the context of respects to other people's rights.

Human Rights is the term changing the term of Basic Rights. Besides, there is also the term of Fundamental Rights and Basic Rights. According to Muladi, the definition of Human Rights is the inherent rights attached to human since they were born, and without the rights, the human cannot grow and develop as the whole human. Considering the importance of it, Muladi adds that without human rights, the human cannot develop their talent and fulfill their needs[18].

The formulation of Human Rights in Law Number 39 Year 1999 regarding Human Basic Right Article 1 section 1 defines that human rights is a group of rights attached to God's creature and become a respected blessing which is upheld and protected by state of law, Government, and every people for the sake of dignity as well as prestige protection to human. This protection covers the fundamental rights and freedoms of children, along with various necessities related to children's welfare.

The Law of Children's Protection No.23 Year 2002 (UU PA) regarding the Rights and Position of Children regulates that:

1. Children have a right of the name, identity, and nationality status (Article 5);

2. Children's identity has to be given since they were born (Article 27);

3. This identity is inserted in children's birth certificate (Article 28), the creation of children's birth certificate becomes the responsibility of the government, and village officials do the execution of it.

\subsection{Third Main Discussion}

To answer the question: "How is the political construction of law to the acknowledgment of marriage based on Pancasila as the means to protect the children?", these following two sub-sections are going to explain the cases.

3.3.1. Politics of Law.Mahfud MD[16] defines that politics of law are legal policies which are practiced nationally by Indonesia government; including; first, the development of law which focuses on the formulation and update of legal materials as needed; second, the practice of law provision which includes the function of institution and development to law enforcer. Mahfud[16] explains that the political configuration of a country will bear a specific character of legal product in this respective country.

Concerning the strength of politics to law, Dahrendorf says that law is the reflection of power holder or related to power. Mahfud explains that the political configuration of a country will bear a particular character of legal product in this respective country. In a country with a democratic political configuration, the right product will be responsive/populist. Meanwhile, in the authoritarian country, the right product will be orthodox/conservative/elitist. Responsive/populistic right product is a legal product reflecting justice and fulfilling society's need. The process of making the law in this country gives a considerable portion and full participation of social groups or individuals in society. 
The result of the product is responsive to the demands of social groups or individuals in society.

Meanwhile, the orthodox/conservative/elitist product is a legal product which content reflects the social vision of political elites, more likely to figure out government aims, and positivist-instrumentalist (becomes the tool to the practice of ideology and country's program). Contradictory to responsive law, customary law is more closed to the demands of society or individuals in society. Society's participation is relatively small in this country. In order to classify whether a legal product is responsive or conservative, the used indicator is a legal process, characteristics, the function of law, and the possibility of law interpretation.

3.3.2. The Concept of State of Law based on Pancasila. The concept which is upheld by Indonesia from its independence as the state of the law is not Rechtsstaator Rule of Law. Instead, Indonesia formulated a new concept of law based on the political philosophy of Pancasila, which becomes the characteristics which differentiate Indonesia's legal system to another legal system. Wherein, if it is related to the literature of combined social value, it is chosen as a prismatic choice in a legal context which is called as prismatic law. The characteristics of Pancasila state of law are: first, it builds a country based on kinship; wherein the legal rights of individuals, specifically to property ownership and fundamental rights are acknowledged under the priority of national needs; second, it is a country with guarantee and justice, combining the principle of legal assurance with justice as well as other concept and system: for example, local custom and religious norms in Indonesia; third, it is a religious nation-state. Religious means that the country's life is based on the deictic beliefs providing freedom to its people to embrace different religions; fourth, combining law as the tool of change from the society and law as the cultural reflection of the society along with preserving and reflecting the living law and its positivity to stimulate and direct the society to the development and advancement of the country based on the principles of Pancasila; fifth, the creation and formation of national law should be based on legal principle which is neutral and universal that it should fulfill the main requirement of Pancasila as the bonding of the nation.

The building of national legal system based on prismatic law of Pancasila is hoped to construct the law of marriage which is based on Pancasila as the foundation of children's protection, especially for children outside of marriage.

\section{Conclusion}

\subsection{Conclusion}

- Recently, judges who decide the case in a positivistic way should be left out due to their incapability of providing substantive justice. It becomes complicated because human is complex and dynamic that it is almost impossible to have precise regulation on everything that happens. The Resolution of CCI No. 46/PUUVIII/2010 regarding Children outside of Marriage becomes the harmonization of national law to global/international law; since the Resolution of CCI provides substantive justice which is impossibly obtained from Law of Marriage, especially in its Article 43 section (1), due to its contradiction to the second principle of Pancasila and the 1945 Constitution of Indonesia Article 28B section (2) and Article 28D section (2), which relate to the formulation of Human Basic Rights (the rights of the child) and Global law in international law of Convention of the 
Rights of Child (CRC). For CCI, Pancasila is the stepping foundation for every policy made.

- Politics of law to the country's acknowledgment has not fulfilled the second principle of Pancasila. It is because political activity prioritizes positivist paradigm which runs for legal insurance; despite it neglects justice and humanity, legal pluralism, and fundamental human rights, making the goals of people's welfare improvement, mainly rural and poor people, are not reached.

- There should be a legal reconstruction from the creation of law and its implementation which refers to the theory of triangular legal pluralism of Werner Menski which combines synergy between the needs of law from the country to globalization and human fundamental rights which is developing in international scope, national law, and reality of pluralism from local people; wherein based on the values respected by Indonesian as the Grundnorm, i.e. Pancasila. The concept of Pancasila-based state of the law becomes the main characteristic which differentiates the legal system of Indonesia to another legal system in the world. Wherein, if it is related to the literature of combined social value, it is chosen as a prismatic choice in a legal context which is called as prismatic law.

\subsection{Suggestions}

- The government should make or revise the Law of Marriage based on five characteristics of the state of the law on Pancasila principles to stop the conflict between the local community, religious people, poor people, and government themselves in terms of marriage registration. It will result in the validity of the marriage and the valid status of the children.

- The building of a national legal system in the future should be based on Pancasila to construct the law to protect children (especially children outside of marriage). Pancasila in cultural perspective sees the essence of its principle as the unity of invention, feels, and contribution to the whole nation. Somehow, reality shows the gap between Pancasilavalue's practices. In the writers' opinion, the registration of marriage can still be regulated under the provision of the implementing regulation.

\section{References}

[1] G. F. Bell, "Multiculturalism in Law is Legal Pluralism-Lessons from Indonesia, Singapore, and Canada," Singapore J. Leg. Stud., pp. 315-330, 2006.

[2] Hee-Ho Pak, "Legal Pluralism in Indonesia," HUFS Law Rev., 2012.

[3] A. Bedner and S. Van Huis, "Plurality of marriage law and marriage registration for Muslims in Indonesia: a plea for pragmatism," Utr. Law Rev., 2010.

[4] Suwanee, "Dualism of Unregistered Marriage Law in Indonesia," J. Law, Policy Glob., no. 67 , p. $110,2017$.

[5] P. Duff, S. Kusumaningrum, and L. Stark, "Barriers to birth registration in Indonesia," The Lancet Global Health. 2016.

[6] I. Abdullah, "Legal Protection Setting of Post-Divorce Women's Rights: Case Study of Siri Marriage in Lombok," Mediterr. J. Soc. Sci., 2017.

[7] A. M. Buttenheim and J. Nobles, "Ethnic diversity, traditional norms, and marriage behaviour in Indonesia," Popul. Stud. (NY)., 2009.

[8] S. van Huis and Wirastri, "Muslim Marriage Registration in Indonesia: Revised Marriage 
Registration Laws Cannot Overcome Compliance Flaws," Aust. J. Asian Law, vol. 13, no. 1, pp. 1-17, 2012.

[9] S. Butt, “Asia-Pacific: 'Illegitimate' children and inheritance in Indonesia," Altern. Law J., 2012.

[10] T. Hutchinson and N. Duncan, "Defining and Describing What We Do: Doctrinal Legal Research," Deakin Law Rev., 2012.

[11] M. Mietzner, "Political conflict resolution and democratic consolidation in Indonesia: The role of the constitutional court," J. East Asian Stud., 2010.

[12] Suteki, Rekonstruksi Politik Hukum: Hak Atas Air, Pro Rakyat. Malang: Surya Pena Gemilang, 2009.

[13] M. Thohir, "Peranan Teori-Teori Sosial Untuk Memahami Fenomena Hukum Dalam Kehidupan Sosial." Matriculation Board of PDIH UNDIP, Semarang, p. 3, 2014.

[14] M. M.D., Mahfud, Membangun Politik Hukum, Menegakkan Demokrasi. LP3ES, 2006.

[15] Muladi, Demokratisasi, Hak Asasi Manusia and Reformasi Hukum Indonesia. Jakarta: The Habibie Center, 2002.

[16] M. M.D., Mahfud, Politik Hukum di Indonesia. Jakarta: LP3ES, 2006. 